\title{
Monitoring of Change in Cantaloupe Fruit Quality under Pre-Cooling and Storage Treatments
}

\author{
Azam MM ${ }^{1,2^{*}}$, Eissa $\mathrm{AHA}^{1,2}$ and Hassan $\mathrm{AH}^{1}$ \\ ${ }^{1}$ Department of Agriculture Systems Engineering, College of Agricultural and Food Sciences, King Faisal University, Saudi Arabia \\ ${ }^{2}$ Agriculture Engineering Department, Faculty of Agriculture, Minoufiya University, Shibin El-Kom, Egypt
}

\begin{abstract}
During recent years, global concern for protection of the environment has led researchers to improving postharvest treatments such (precooling, handling, storage, etc.,). The present investigation was also directed to find out the precooling and storage alternatives for the extension of the storage life of cantaloupe fruits (Cucumis melon). Fruits were harvested at the mature stage and precooled by forcing cooling air with velocity of $1-2 \mathrm{~m} / \mathrm{s}$ at three different air temperatures of $5^{\circ} \mathrm{C}, 10^{\circ} \mathrm{C}$ and $15^{\circ} \mathrm{C}$. The fruits were analyzed for physiological characters such as loss in weight, fruit firmness, change in color surface of fruit and its flesh. Fruit temperature expectedly decreased from initial level of about $36-38^{\circ} \mathrm{C}$ to the desired storage temperature of $10^{\circ} \mathrm{C}$ by forcing cooling air at $5^{\circ} \mathrm{C}$, for about $45 \mathrm{~min}$. Cooling time increased to 105 and 165 min when cooling air temperature increased to $10^{\circ} \mathrm{C}$ and $15^{\circ} \mathrm{C}$, respectively. During subsequent storage at $15^{\circ} \mathrm{C}$ with $90-95 \%$ relative humidity, precooled fruits were exhibit more desirable characteristics than that of non-precooled fruits (control), where precooling was retard softening. Non precooled fruits "control" turned ripe-soft after 15 days when firmness decreased to less than $10 \mathrm{~N}$ from initial value of $90 \mathrm{~N}$ at the unripe stage.
\end{abstract}

Keywords: Cantaloupe; Forced air cooling; Cold storage; Color; Firmness; Quality

\section{Introduction}

No doubt that fruits and vegetables considered a major component of vitamins, antioxidants, minerals, dietary fiber [1]. Both quantitative and qualitative postharvest losses in fresh fruits and vegetables are significant due to their high values reaching up to $50 \%$ in developing countries [2]. Therefore, postharvest conservation of the produce quality and quantity is an important measurement to enhance world food supplies in a largely effective manner [3]. Certainly improved technologies in postharvest can at some extent overcome these losses. Temperature and relative humidity are the most important environmental factors affecting quality of fresh produce and also the consumer acceptability for fruits and vegetables displayed in a produce department. Good temperature management is the simplest and easiest way of delaying produce deterioration and it can be applied through low storage temperatures which can depress physiological activity of tissues and activity of spoilage microorganisms, and, in general, the lower the storage temperature, the longer the produce postharvest life $[4,5]$. In a tropical environment, high temperature and high relative humidity were frequently occurred throughout the year and they will affect postharvest quality of fruit, include melon fruit quality. Several methods were applied for rapid cooling the product to the lowest safe storage temperature within hours of harvest, reducing the respiration rate and enzyme activity, slower ripening/senescence, maintenance of firmness, inhibition of pathogenic microbial growth and minimal water loss [6].

Temperature is the most single important factor which affects the storage life and the quality of fresh produce. The process of precooling is the removal of field heat as soon as possible after harvest since field heat arrest the deterioration and senescence process. The precooling process can be achieved via different methods. Forced air precooling is the most common technique and is adapted to many commodities [7].

Pre-cooling by removing field heat from freshly harvested fruits reduces microbial activity and respiration rates. Furthermore, the respiratory activity and senescence of fruit as well as ethylene production are temperature dependent. Due to the pre-cooling treatments, metabolic activity and consequently respiration rate and ethylene production of the fruits were reduced considerably. This also decreases the ripening rate, diminishes water loss and decay, and thus, helps preserving quality and prolongs shelf life of the fruits [8]. Thompson et al. [9] defined forced-air cooling as a technique of forcing cold air through containers, cooling individual pieces of product. It is commonly used for tree fruit, berries, melons and cut flowers. Forcedair cooling advantages include ease of use, rapid cooling and a dry product [10]. Color may be defined as the impact of the wavelengths of light in the visual spectrum, from 390 to $760 \mathrm{~nm}$, on the human retina and is one of the major attributes which affect the consumer perception of quality [11]. Color is one of the main attributes that characterizes the freshness of most fresh-cut fruits and vegetables, as consumers take product appearance as a primary criterion in food choice and acceptability, and may even influence taste thresholds, sweetness perception and pleasantness [12].

The quality of the cantaloupe fruits are characterized by different factors that are associated with the characteristics of flesh as the soluble solids content, external and internal appearance of fruit, the thickness of the pulp and its aroma and flavor and all these characteristics determine the acceptance of the fruit by consumers and also are used as an index for grading and marketing [13].

The initial quality of the cantaloupe, based on physical appearance such as the size, net development, background colour, and being free

*Corresonding author: Azam MM, Department of Agriculture Systems Engineering, College of Agricultural and Food Sciences, King Faisal University, Saudi Arabia, Tel: 009665895719; E-mail: mazam@kfu.edu.sa

Received October 12, 2015; Accepted November 03, 2015; Published November 12,2015

Citation: Azam MM, Eissa AHA, Hassan AH (2015) Monitoring of Change in Cantaloupe Fruit Quality under Pre-Cooling and Storage Treatments. J Food Process Technol 6: 527. doi:10.4172/2157-7110.1000527

Copyright: ( 2015 Azam MM, et al. This is an open-access article distributed unde the terms of the Creative Commons Attribution License, which permits unrestricted use, distribution, and reproduction in any medium, provided the original author and source are credited. 
Citation: Azam MM, Eissa AHA, Hassan AH (2015) Monitoring of Change in Cantaloupe Fruit Quality under Pre-Cooling and Storage Treatments. J Food Process Technol 6: 527. doi:10.4172/2157-7110.1000527

Page 2 of 6

from defects is a basic criterion for fruit to be selected for fresh-cut processing. These fruits all show rapid quality degradation when put into storage [14-16]. The quality reduction may be tolerated under optimum postharvest handling and a storage temperature of between $0^{\circ} \mathrm{C}$ and $1^{\circ} \mathrm{C}$. These conditions have been previously recommended for delaying deterioration and for ripening. Interest in reducing the amount of fruit dumping at fresh fruit markets has led to an observation of how the cantaloupe undergoing a longer duration of postharvest storage may preserve and maintain the fresh quality after processing. The objective of this study is to determine the effect of forced air cooling, in combination with storage period to enhance the quality and characteristics of cantaloupe fruits.

\section{Materials and Methods}

\section{System experimental design}

The freshly harvested fruits sorted by size, color and absence of defects to see effect of fast heat removal on cantaloupe properties. Cooling air was forced in a refrigeration room at $5^{\circ} \mathrm{C}, 10^{\circ} \mathrm{C}$ and $15^{\circ} \mathrm{C}$ with air velocity of $1-2 \mathrm{~m} / \mathrm{s}$. During pre-cooling, two fruits were penetrated with thermocouple for temperature monitoring. Temperature was measured every $5 \mathrm{~min}$. After attaining the required temperature $10^{\circ} \mathrm{C}$, fruits were shifted after cooling to foam box which was set in cooled room maintained at $10^{\circ} \mathrm{C}$. Some physical and mechanical properties of fruits were studied before and after pre-cooling processes to set the change in fruit quality properties. Fruits without forced air-precooled served as control. The study was done following procedures for completely randomized design experiments. Four replications were used, each replication having 4 fruits per observation period (Figure 1). Cantaloupes were considered cooled when they reached $7 / 8$ of the cooling time, which is the time necessary for a reduction of $87.5 \%$ of the initial fruit temperature with respect to air temperature [9].

After pre-cooling process, samples were stored in storage unit for 15 days $\left(10^{\circ} \mathrm{C}\right.$ and $90 \pm 5 \%$ Relative humidity) while sample without forced air-precooled (control) placed in room temperature $\left(23^{\circ} \mathrm{C}\right.$ and $78 \%$ Relative humidity). Through the storage period $(0,5,10,15$ day), changing in fruit properties such as firmness and color were measured. Data were collected and incorporated into the computer to make the necessary statistical analysis at this stage to identify the most important results of this study (Figure 1).

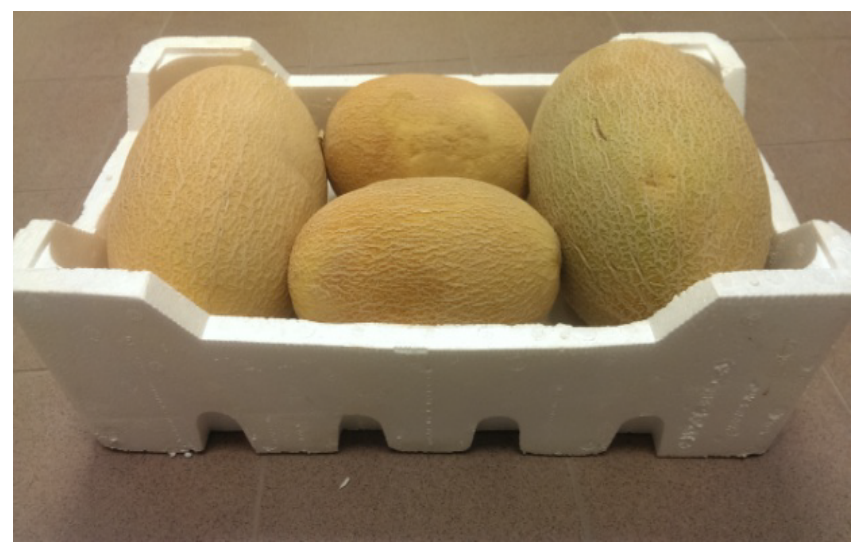

Figure 1: Box for pre-cooling cantaloupe products.

\section{Measurement of Fruit Responses}

\section{Color determination}

Color was determined using the Hunter Lab System with a Minolta colorimeter CR320 model (Figure 2a). Chroma values were the means of three determinations for each fruit along the equatorial axis. The lightness $L, a$ and $b$ values were converted to standard $L^{\star}, a^{*}$ and $b^{\star}$ values as [17]. The $\mathrm{L}^{*}$ (lightness), $\mathrm{a}^{*}$ and $\mathrm{b}^{*}$ (chromaticity) coordinates. The cantaloupe fruit (flesh, skin) color was measured for $\mathrm{L}^{\star}, \mathrm{a}^{\star}$ [green $(-)$ to red $(+)$ ], $b^{*}$ [blue (-) to yellow (+)] (Figure $2 b$ ): [18]

$$
\begin{aligned}
& L^{*}=\frac{100 L}{255} \\
& a^{*}=\frac{240 a}{255}-120 \\
& b^{*}=\frac{240 b}{255}-120
\end{aligned}
$$

The hue angle $\left(H^{\circ}\right)$ and chroma $\left(C^{\star}\right)$ values and the total color difference $(\Delta E)$ were calculated as

$$
\begin{aligned}
& H^{o}=\tan ^{-1}\left(\frac{b^{*}}{a^{*}}\right) \\
& C^{*}=\left(a^{* 2}+b^{* 2}\right)^{1 / 2} \\
& \Delta E=\left[\left(L^{*}-L_{o}^{*}\right)^{2}+\left(a^{*}-a_{o}^{*}\right)^{2}+\left(b^{*}-b_{o}^{*}\right)^{2}\right]^{0.5}
\end{aligned}
$$

\section{Fruit firmness}

Digital instrument (Effe-Gi, Ravenna, Italy) for measuring penetration resistance was used to measure firmness, which is used worldwide as a test of ripeness and maturity for many vegetables and fruits. Firmness for fruit was measured by two methods. First one measured the firmness for full fruit as showed in (Figure 3A) (beginning of the neck region), while the second method measured firmness for flesh fruit in four points (f1, f2, f3, f4) as showed in Figure 3.

\section{Weight loss}

It was calculated as the difference between the initial (prior to storage) weight and the final weight (after storage).

\section{Results and Discussion}

Figure 4, indicates the rate of decrease in pulp temperature during forcing cooling air at $5-15^{\circ} \mathrm{C}$. Bringing down the fruit temperature from about $36-38^{\circ} \mathrm{C}$ to the desired storage temperature of $10^{\circ} \mathrm{C}$ was

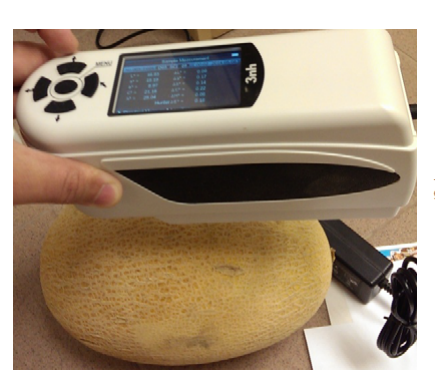

A

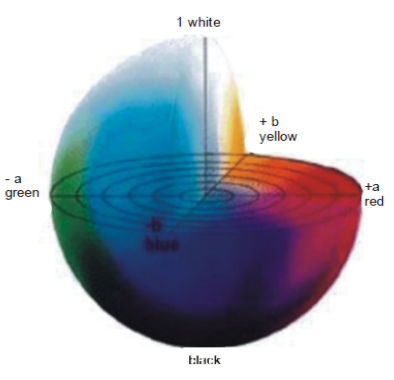

B
Figure 2: CILAB color space (A), and Minolta colorimeter CR320 model (B). 


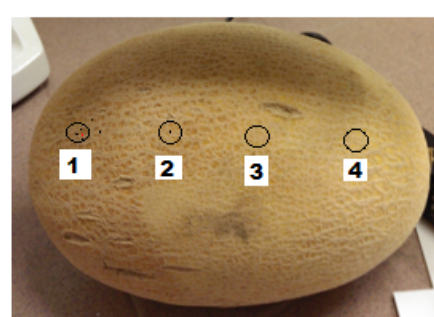

A

Figure 3: Measured firmness for full and flesh fruit melon.

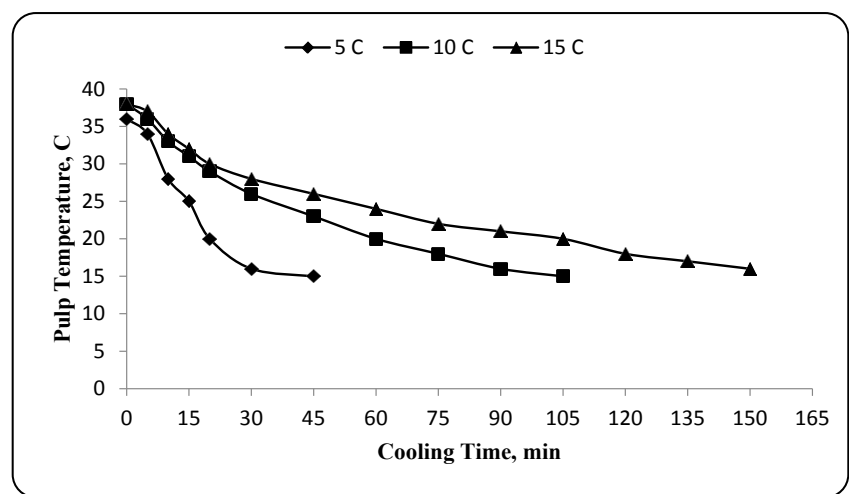

Figure 4: Changes in pulp temperature of cantaloupe during force air cooling at $15^{\circ} \mathrm{C}$.

expectedly fastest at $5^{\circ} \mathrm{C}$ and slowest at $15^{\circ} \mathrm{C}$. It took about $45 \mathrm{~min}$ for the pulp temperature to drop to $10^{\circ} \mathrm{C}$ by cooling air of $5^{\circ} \mathrm{C}$ and about $165 \mathrm{~min}$ by cooling air of $15^{\circ} \mathrm{C}$. At cooling air of $10^{\circ} \mathrm{C}$, the time spent to reduce the pulp temperature to $10^{\circ} \mathrm{C}$ was about $105 \mathrm{~min}$. During subsequent $10^{\circ} \mathrm{C}$ storage, forced air-precooled fruits did not exhibit desirable characteristics indicative of more favorable treatment effects for quality maintenance and shelf life extension.

\section{Firmness}

Data in Figure 5 showed the changing in skin cantaloupe firmness under precooling and storage treatments. The values of skin firmness were varied from 44.65 to $76.65 \mathrm{~N}$ for cantaloupe cooling treatment, and from 49.50 to $112 \mathrm{~N}$ for cantaloupe without cooling treatment (control). Samples of all treatments showed decrease in flesh and full fruit firmness during all storage period.

Fruits which were stored without cooling (control) showed a skin softening at end of storage period. Mean values of treatments also revealed that fruit stored after cooling had lower pulp firmness. This indicates that the firmness of fruits was decreased as postharvest storage of the cantaloupe increased. It can be concluded that in comparison between treatment (with cooling and without cooling) the experimental results of measuring firmness in cantaloupe which precooled were pretty much comparable with each other. From Table 1, average values of firmness of fresh cantaloupe decreased from 97.73 $\mathrm{N}$ to $67.33 \mathrm{~N}$ for stored precooled fruit and from $99.67 \mathrm{~N}$ to $62.63 \mathrm{~N}$ for stored non-cooled fruit as the storage period increased. And data in Figure 6 showed the effect of postharvest storage of cantaloupe on the flesh fruit firmness, which stored at $10^{\circ} \mathrm{C}$ and $90 \pm 5 \% \mathrm{RH}$ for 15 days. The slides that pre-cooled before storage recorded lowest values of firmness compared to slides stored without cooling. Differences in

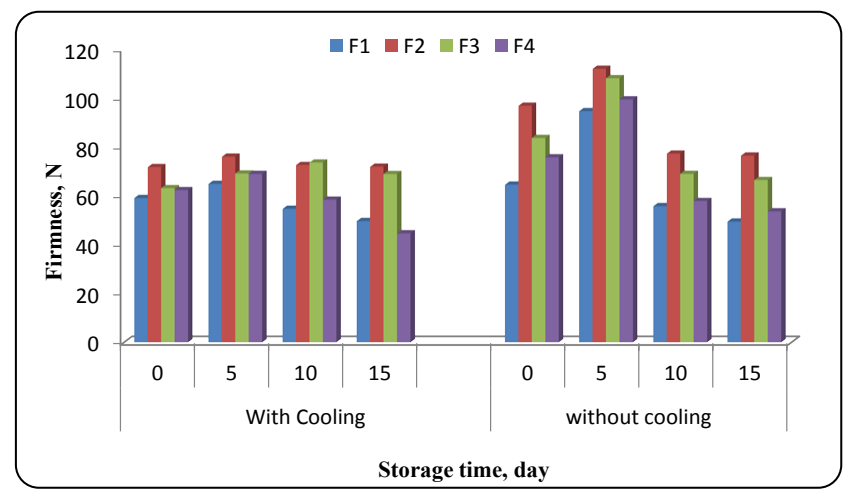

Figure 5: Effect of precooling treatment and storage time on firmness of full cantaloupe.

the percentage loss were affected by the fruits and storage duration. This indicates that the firmness of the flesh fruits were decreased as storage period of the cantaloupe increased as shown in Figure 6. Values of flesh fruit firmness which stored without cooling were increased at the second period (after 5 day) due to the high percentage of water loss while, it was decreased during the next periods from the harvesting day. But same values of flesh fruit firmness which stored after cooling recorded highest values in the end of storage period ( 15 day). This is may be due to some changing occurred in flesh fruit as shrinkage due to the high water loss percentage particularly during the period of first week from harvesting day (Table 1).

\section{External and internal color}

External (skin) color: Fruit which harvested at maturity stage showed an increase in yellow color development. There were differences between color parameters of skin fruit $\left(L^{*}, a^{*}, b^{*}, h^{*}, \Delta \mathrm{L}^{*}\right.$, $\Delta \mathrm{a}^{*}, \Delta \mathrm{b}^{*}, \Delta \mathrm{h}^{*}, \Delta \mathrm{E}$ ) under different treatments (Figure 7). Data showed correlation between different treatments and $\mathrm{a}^{*}$ values. $\mathrm{a}^{\star}$ values were increased when skin fruit reached from immature to full matured stage. An increasing in $a^{*}$ value means a decrease in the degree of greenness. Meanwhile, mean values of color parameters of skin fruit decreased over the postharvest storage time of the fruit. The decreases of color in the skin cantaloupe fruits were obviously associated with the ripeness stage of the fruit [19].

Maximum value of $a^{*}$ (19.37) was found at treatment without cooling after 10 days storage, while maximum value of $a^{*}$ at treatment with cooling (18.74) was found at the end of storage period. At the end of storage period values of $a^{*}$ were reached to 18.74 and 13.84 for treatments with and without cooling, respectively. These changing during storage periods (loss of greenness) were occurred as a result of breakdown of chlorophyll pigments in the peel tissues. The change of peel color from green to yellow was due to accumulation of carotenoids and chlorophyll degradation at thylakoid membrane through chlorophyllase and oxidase enzymes.

Values of $b^{*}$ were increased between treatments under this study. This values ranged from 7.71 to 9.14 in treatment with cooling, and ranged from 5.52 to 8.61$)$ in treatment without cooling. Similarly, the luminosity $\left(L^{*}\right)$ varied in same fashion (Figure 7). These results are in close agreement to those of earlier workers [20]. The luminosity $\left(L^{*}\right)$ of the skin fruit recorded similar values of 16.88 and 16.23 for treatment with-cooling and without cooling, respectively. But in end of the storage period, the value of $\mathrm{L}^{*}$ of the skin fruit had a value of 16.44 


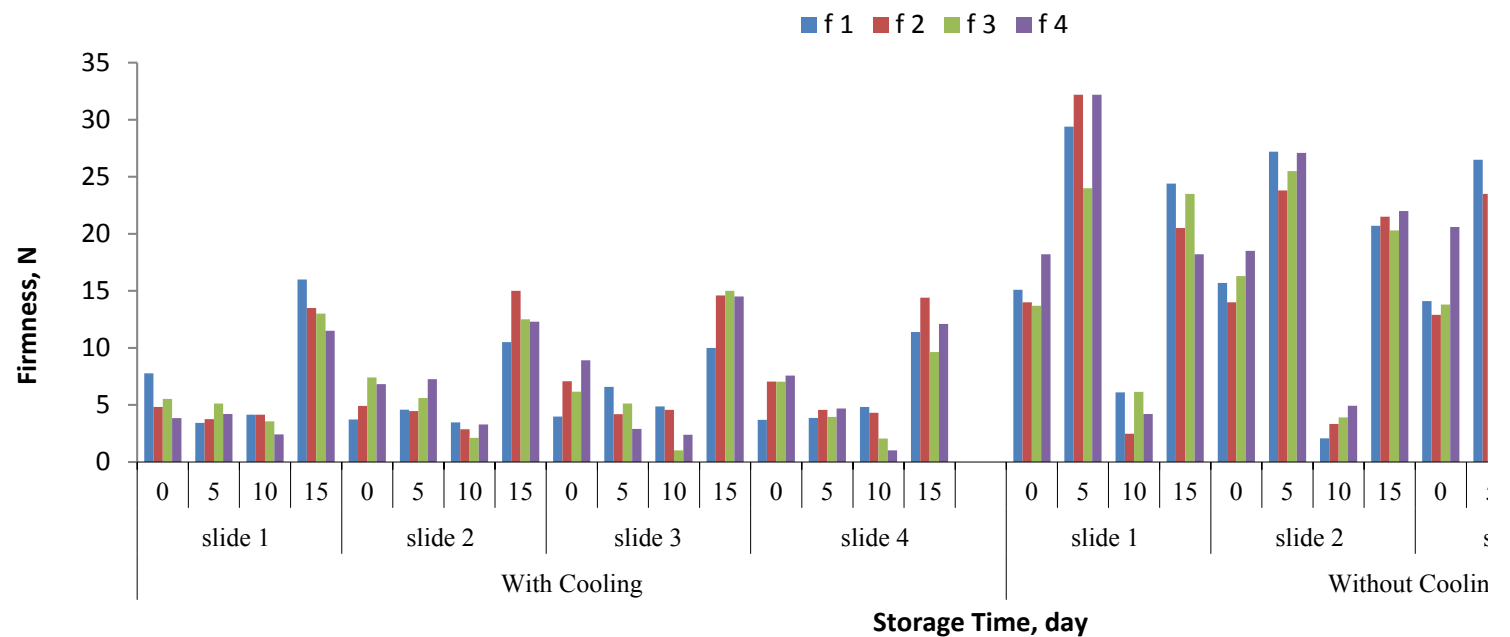

Figure 6: Effect of precooling and storage period treatments on flesh fruit firmness.

\begin{tabular}{|c|c|c|c|c|c|c|c|c|c|c|c|c|c|}
\hline Treatment & Storage period & Firmness & $\mathbf{L}^{*}$ & $a^{*}$ & $\mathbf{b}^{*}$ & $c^{*}$ & $\mathbf{h}^{*}$ & $\Delta \mathbf{L}^{*}$ & $\Delta \mathbf{a}^{*}$ & $\Delta \mathbf{b}^{*}$ & $\Delta \mathbf{C}^{*}$ & $\Delta \mathbf{h}^{*}$ & $\Delta \mathbf{E}$ \\
\hline \multirow[t]{4}{*}{ With Cooling } & Period 1 & 70.11 & 16.88 & 18 & 9.14 & 20.19 & 26.91 & 0.31 & 0.21 & 0.41 & 0.38 & 0.71 & 1.34 \\
\hline & Period 2 & 97.73 & 15.85 & 18.29 & 7.71 & 19.85 & 22.86 & -0.38 & -1.26 & -0.60 & -1.39 & 0.08 & 0.95 \\
\hline & Period 3 & 79.28 & 16.38 & 18.47 & 8.41 & 20.29 & 24.47 & 0.96 & 0.22 & 1.09 & 0.68 & 0.88 & 0.89 \\
\hline & Period 4 & 67.33 & 16.69 & 18.97 & 8.76 & 20.89 & 24.80 & 0.22 & 0.11 & 0.23 & 0.2 & 0.17 & 0.22 \\
\hline \multirow[t]{4}{*}{ Without Cooling } & Period 1 & 80.25 & 16.23 & 18.55 & 8.26 & 20.30 & 24 & 0.01 & 0.06 & 0.01 & 0.06 & 0.02 & 0.04 \\
\hline & Period 2 & 99.67 & 15.20 & 15.48 & 6.69 & 16.86 & 23.38 & 0.16 & 0.34 & 0.19 & 0.39 & 0.04 & 0.27 \\
\hline & Period 3 & 69.63 & 16.49 & 19.37 & 8.61 & 21.19 & 23.96 & -0.1 & -0.11 & -0.15 & -0.16 & 0.09 & 0.13 \\
\hline & Period 4 & 62.63 & 14.17 & 13.84 & 5.52 & 14.90 & 21.73 & 0.53 & 2.18 & 0.81 & 2.33 & 0.05 & 1.52 \\
\hline
\end{tabular}

Table 1: Means for firmness, color properties of fresh cantaloupe, which were stored after cooling at $10^{\circ} \mathrm{C}$ and $90 \pm 5 \% \mathrm{RH}$ for 15 days.

and 14.17 for treatment with-cooling and without cooling, respectively. Meanwhile, mean values of luminosity $\left(\mathrm{L}^{\star}\right)$ of the skin fruit decreased over the postharvest storage time of the fruit. The decrease of color brightness in the skin cantaloupe was obviously associated with the ripeness stage of the fruit [19] and Figure 7 showed the hue angle $\left(h^{*}\right)$ of the skin cantaloupe. The hue angle $\left(h^{*}\right)$ values for fruit which prepared by cooling were recorded a largest values than sample without cooling during all storage period.

Yellowing of the peel and pulp based on increases in $b^{*}$ values proceeded at a relatively reduced rates in precooled fruits than in nonprecooled ones (control). This was noted after 15 days of storage, with the $5-10^{\circ} \mathrm{C}$ precooling treatment causing consistently lower $b^{*}$ values and hence reduced rate of yellowing of both peel and pulp. Changes in $L^{*}$ values did not reflect the increasing degree of yellowing with ripening of the fruit. However, in terms of softening, precooling had no delaying effect.

Internal (flesh) color: In flesh fruit, intensity of yellow color is an important quality property. The color is primarily due to carotenoid pigments. Values of color parameters such $\mathrm{L}^{*}, \mathrm{a}^{*}$ and $\mathrm{b}^{*}$ varied under all treatments (Figure 8 ). The maximum values for $\mathrm{L}^{*}, \mathrm{a}^{\star}, \mathrm{b}^{*}$ and $\mathrm{C}^{*}$ were 20.84, 20.15, 14.74 and 24.96 with treatment (cooling), and were 20.93, 19.37, 13.71 and 24.45 in treatment (without cooling). Data showed that values of $\mathrm{a}^{\star}, \mathrm{b}^{\star}$ and $\mathrm{C}^{\star}$ were decreased with increasing in $\mathrm{L}^{*}$ value. Variation in color parameters during storage period may be to the burst of ethylene gas that signals genes to transform chloroplasts, chlorophyll is gradually replaced by the carotenoids.
The results for chromaticity $\left(\mathrm{C}^{*}\right)$ as shown in Figure 8 were used to observe the orange color purity of the flesh cantaloupe. The chromaticity of the flesh cantaloupe prepared after two weeks of postharvest storage decreased by the end of the sample storage. After 15 days of storage, the chromaticity value of the flesh cantaloupe was dramatically decreased along with its brightness $\left(\mathrm{L}^{*}\right)$. The decrease in the color purity may be caused by the occurrence of physical damage during fresh-cut processing. The lack of maintenance of the cutting utensils, for example using a blunt knife, can be the main cause of the development of surface darkness or a decrease in the yellow color of the cantaloupe [21]. From Table 2, mean values of firmness of flesh cantaloupe decreased from 11.98 to $4.32 \mathrm{~N}$ for stored precooled fruit and from 27.22 to $4.78 \mathrm{~N}$ for stored non-cooled fruit as the duration of postharvest storage increased. This indicates that the delay of fresh fruit processing prior to postharvest ripening resulted in texture quality degradation over the sample storage period.

Weight losses: Data showed that, lower physiological occurred in weight of fruits with each treatment. Meanwhile, Pre-cooled fruits exhibited relatively slower loss in weight on the corresponding dates as compared to the non-pre-cooled (Figure 9). This may be due to the fact that loss of moisture from pre-cooled commodities is slower if higher relative humidity is maintained in the storage atmosphere [22]. And generally, data showed that losses in weight of fruit increasing with the increasing of storage period then decreased at the end of storage period for different treatments. Data revealed that fruits which precooled generally had the minimum physiological weight loss. The lowest physiological weight loss value recorded (1.15\%) with fruits 


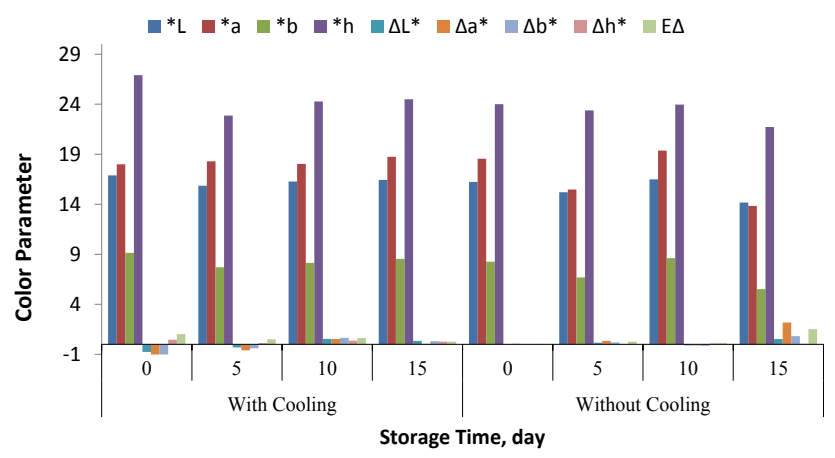

Figure 7: Effect of pre-cooling and storage time treatments on color parameters of skin fruit.

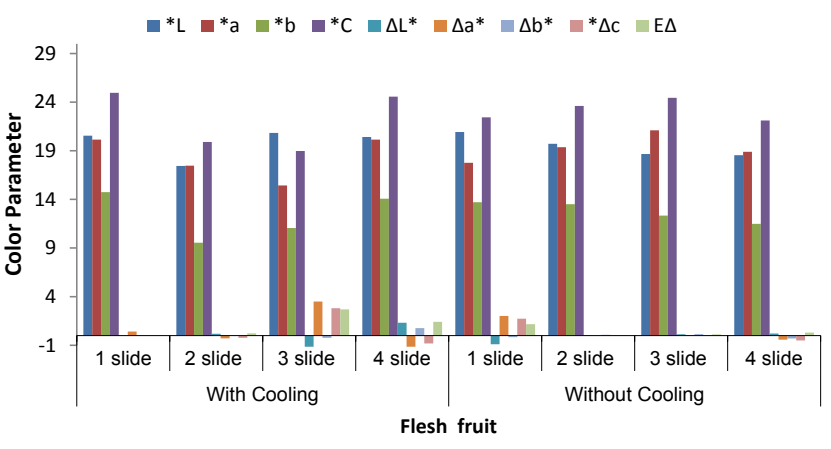

Figure 8: Effect of pre-cooling treatment on flesh color of cantaloupe fruit.

\begin{tabular}{|c|c|c|c|c|c|c|c|c|c|c|c|c|c|}
\hline Treatment & Storage period & Firmness & $L^{*}$ & $a^{*}$ & $\mathbf{b}^{*}$ & $\mathbf{c}^{*}$ & $h^{*}$ & $\Delta \mathbf{L}^{*}$ & $\Delta \mathbf{a}^{*}$ & $\Delta \mathbf{b}^{*}$ & $\Delta \mathbf{C}^{*}$ & $\Delta \mathbf{h}^{*}$ & $\Delta \mathbf{E}$ \\
\hline \multirow[t]{4}{*}{ With Cooling } & Period 1 & 4.79 & 20.55 & 20.15 & 14.74 & 24.96 & 36.18 & -0.03 & -0.01 & -0.02 & -0.01 & 0.01 & 0.02 \\
\hline & Period 2 & 11.98 & 17.44 & 17.47 & 9.54 & 19.90 & 28.64 & 0.18 & -0.29 & 0.04 & -0.23 & 0.18 & 0.22 \\
\hline & Period 3 & 6.78 & 20.84 & 15.43 & 11.05 & 18.98 & 35.60 & -2.28 & 3.49 & -0.24 & 2.81 & 2.08 & 2.69 \\
\hline & Period 4 & 4.32 & 20.41 & 20.15 & 14.07 & 24.57 & 34.92 & 1.32 & -1.52 & 0.76 & -0.81 & 1.55 & 1.41 \\
\hline \multirow[t]{4}{*}{ Without Cooling } & Period 1 & 13.9 & 20.93 & 17.76 & 13.71 & 22.44 & 37.67 & -0.89 & 2.02 & -0.17 & 1.73 & 1.06 & 1.16 \\
\hline & Period 2 & 27.22 & 19.71 & 19.37 & 13.51 & 23.61 & 34.90 & 0.03 & -0.03 & 0.08 & 0.02 & 0.09 & 0.04 \\
\hline & Period 3 & 20.78 & 18.66 & 21.10 & 12.34 & 24.45 & 30.31 & 0.13 & -0.05 & 0.14 & 0.02 & 0.14 & 0.11 \\
\hline & Period 4 & 4.78 & 18.55 & 18.89 & 11.49 & 22.11 & 31.31 & 0.21 & -0.42 & 0.3 & -0.51 & 0.04 & 0.31 \\
\hline
\end{tabular}

Table 2: Means for firmness, color properties of flesh cantaloupe, which were stored after cooling at $10^{\circ} \mathrm{C}$ and $90 \pm 5 \% \mathrm{RH}$ for 15 days.

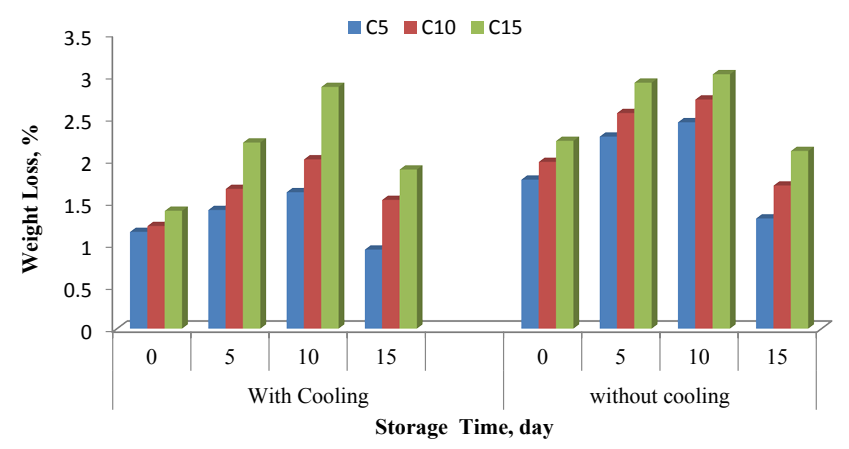

Figure 9: Weight losses (\%) vs storage time (day) of fresh fruit treated with three levels of air precooling temperature $\left(5^{\circ} \mathrm{C}, 10^{\circ} \mathrm{C}, 15^{\circ} \mathrm{C}\right)$.

which precooled at air precooling temperature $\left(5^{\circ} \mathrm{C}\right)$, while the highest physiological weight loss value recorded $(3.02 \%)$ with fruit which non precooled at air precooling temperature $\left(15^{\circ} \mathrm{C}\right)$.

\section{Conclusions}

Forced air cooling could rapidly remove field heat from the fruit which is necessary to reduce refrigeration load during subsequent cold storage at $10^{\circ} \mathrm{C}$. However, it seems to have no beneficial effect on fruit quality and shelf life. In certain cases, it may result to undesirable storage behavior such as the increased in weight loss when fruits were forced air precooled at higher temperatures of $10-15^{\circ} \mathrm{C}$. Cantaloupe allows for postharvest storage at a low storage temperature of $15^{\circ} \mathrm{C}$ and $90 \pm 5 \% \mathrm{RH}$. This is a potential alternative for fresh-cut processing extension, since it provides for reduced physicochemical and microbial changes during storage at cold environment. Firmness, luminosity $\left(L^{*}\right)$, were decreased by increasing the postharvest storage period of the fruit.

\section{Acknowledgement}

The research team would like to thank the Deanship of Scientific Research of King Faisal University, Hofuf, Saudi Arabia, for financial support.

\section{References}

1. Gil MI, Aguayo E, Kader AA (2006) Quality changes and nutrient retention in fresh-cut versus whole fruits during storage. Journal of Agricultural and Food Chemistry 54: 4284-4296.

2. Kader AA (2002) Postharvest technology of horticultural crops. Coop. Ext. Uni. of Ca. Division of Agriculture and Natural Resources. University of CA, Davis, CA.

3. Salunkhe DK, Desai BB (1984) Postharvest biotechnology of fruits. CRC Press, Inc. Boca Raton, Florida 1: 168.

4. Nunes MCN, Emond JP (2002) Storage temperature. In Bartz JA, Brecht JK Postharvest Physiology and Pathology of Vegetables. Marcel Dekker, Inc, New York.

5. Nunes MCN, Emond JP, Rauth M, Dea S, Chau KV, et al. (2009) Environmental conditions encountered during typical consumer retail display, affect fruit and vegetable quality and waste. Postharvest Biol. Technol 51: 232-241.

6. Talbot MT, Chau KV (2002) Precooling strawberries agricultural and biologica engineering department, florida cooperative extension service. Gainesville: Institute of Food and Agricultural Sciences, University of Florida, USA.

7. Elansari AM (2009) Design Aspects in the Precooling Process of Fresh Produce. Global Science Books, Fresh Produce 3: 49-57.

8. Ferreira MD, Brecht JK, Sargent SA, Aracena JJ (1994) Physiological responses of strawberry to film wrapping and precooling methods. Proc. Fla State Hort. Soc 107: 265-269.

9. Thompson JF, Mitchell FG, Rumsey TR, Kasmire RF, Crisosto CH, et al. (1998) Commercial cooling of fruits, vegetables, and flowers. Division of Agricultural and Natural Resources, University of California.

10. Émond JP, Mercier F, Sadfa SO, Bourré M, Gakwaya A, et al. (1996) Study of parameters affecting cooling rate and temperature distribution in forced-air precooling of strawberry. Trans. ASAE 39: 2185-2191.

11. Toivonen PM, Brummell DA (2008) Biochemical bases of appearance and texture changes in fresh-cut fruit and vegetables. Postharvest Biology and Technology 48: 1-14. 
Citation: Azam MM, Eissa AHA, Hassan AH (2015) Monitoring of Change in Cantaloupe Fruit Quality under Pre-Cooling and Storage Treatments. J Food Process Technol 6: 527. doi:10.4172/2157-7110.1000527

12. Clydesdale FM (1993) Color as a factor in food choice. Critical Reviews in Food Science and Nutrition 33: 83-101.

13. Guzmán M, Sánchez A, Valenzuela JL (2009) Postharvest Quality of Melon Fruits in Soil and Soilless Crops. Acta Hort 843: 211-218.

14. Lester $G$ (1996) Calcium alters senescence rate of postharvest muskmelon fruit disks. Postharvest Biology and Technology 7: 91-96.

15. Luna-Guzmán I, Barrett DM (2000) Comparison of calcium chloride and calcium lactate effectiveness in maintaining shelf stability and quality of freshcut cantaloupes. Postharvest Biology and Technology 19: 61-72.

16. Silveira AC, Aguayo E, Chisari M, Artés F (2011) Calcium salts and heat treatment for quality retention of fresh-cut 'Galia' melon. Postharvest Biology and Technology 62: 77-84.

17. Yam KL, Papadakis S (2004) A simple digital imaging method for measuring and analyzing color of food surfaces. Journal of Food Engineering 61: 137-142.
18. Parveen S, Ali MA, Asghar M, Khan AR, Abdus Salam, et al. (2012) PhysicoChemical Changes In Muskmelon (Cucumis Melo L.) As Affected By Harvest Maturity Stage. J Agric Research.

19. Simandjuntak V, Barrett DM, Wrolstad RE (1996) Cultivar and maturity effects on muskmelon (Cucumis melon) colour, texture, and cell wall polysaccharide composition. Journal of the Science of Food and Agriculture 71: 282-290.

20. Soltani M, Alimardani R, Omid M (2011) Changes in physic-mechanical properties of banana fruit during ripening treatment. J Amer Sci 7: 14-19.

21. Machado FLC, Alves RE, Figueiredo RW (2008) Application of 1-methylcyclopropene, calcium chloride and calcium amino acid chelate on fresh-cut cantaloupe muskmelon. Pesq Agro-pec. bras. Brasília 43: 569-574.

22. Lurie SK, Ben AR (1990) Physiological changes in diphenyl treated 'Granny Smith' apples. Israel J Bot 38: 199-207. 